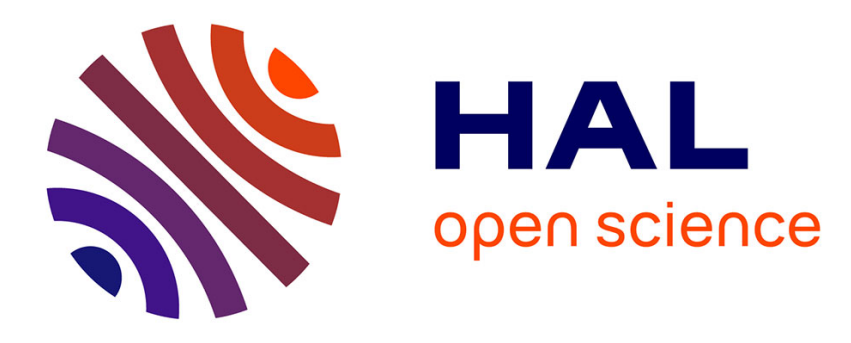

\title{
Epistolary Sketches: Landscapes in a Few Letters by Wordsworth, Shelley and Keats \\ Sylvie Crinquand
}

\section{To cite this version:}

Sylvie Crinquand. Epistolary Sketches: Landscapes in a Few Letters by Wordsworth, Shelley and Keats. Catherine Brace et Adeline Johns-Putra. Process : Landscape and Text, Rodopi, pp.205-223, 2010. halshs-00450731

\section{HAL Id: halshs-00450731 https://shs.hal.science/halshs-00450731}

Submitted on 27 Jan 2010

HAL is a multi-disciplinary open access archive for the deposit and dissemination of scientific research documents, whether they are published or not. The documents may come from teaching and research institutions in France or abroad, or from public or private research centers.
L'archive ouverte pluridisciplinaire HAL, est destinée au dépôt et à la diffusion de documents scientifiques de niveau recherche, publiés ou non, émanant des établissements d'enseignement et de recherche français ou étrangers, des laboratoires publics ou privés. 


\title{
Epistolary Sketches: Landscapes in a Few Letters by Wordsworth, Shelley and Keats
}

\author{
Sylvie Crinquand
}

\begin{abstract}
This paper concentrates on the way in which a few Romantic poets tried to share their first impressions of landscape when addressing close friends or relatives in familiar letters. In these letters, we do not have the poetic re-creation of an artefact inspired by a landscape; because letters are supposed to be spontaneous, they reflect perceptions and emotions with less aesthetic distance than a poem. As such they are revealing, not only of each writer's concerns and reactions, but also of the way his perceptions have been shaped by education and former experiences.
\end{abstract}

Key names and concepts: Byron, Keats, Shelley, Wordsworth, the Alps, Scotland, the sublime, creation, epistolary

In terms of landscape as in many other aesthetic fields, the Romantic perception of the world has had a lasting effect on our collective consciousness. Indeed, to quote Christopher Hussey, the Romantics are more concerned with their own response to the landscape than with the scenery itself: "The romantic mind, stirred by a view, begins to examine itself, and to analyse the effects of the scenery upon its emotions. The picturesque eye, on the contrary, turns to the scene" (Hussey 1983: 84). The master in this respect is of course Wordsworth, whose "Lines Written a Few Miles Above Tintern Abbey" opens with an evocation of the landscape that chooses to introduce an observed scene through sound rather than sight. This poem might be considered the perfect example of how romantic poetry focuses on the viewer's response to nature more than on the way parts of nature are combined by the viewer to create the picture known as a landscape. ${ }^{1}$ Indeed, in Wordsworth's poetry, writing

\footnotetext{
${ }^{1}$ In this respect, English usage differs from the French: in French 'paysage' first evokes the word 'pays' ("Etendue du pays que l'on voit d'un seul coup
} 
landscape can be equated to writing the emotional effect a particular landscape has on a subject who feels at one with his or her surroundings, hence the fitting/fitted theory expressed in the Prospectus to The Recluse.

Such representations of nature in romantic poetry have already been amply discussed, and I have therefore chosen to base my analysis on a different corpus altogether, the travel letters written by some of the Romantics while they were viewing famous landscapes, both in the Alps and in Scotland. A letter is the most immediate form of writing when travelling, if one excepts journals or notebooks. ${ }^{2}$ By reading letters one may hope to have access to these writers' first written impressions, comparable to the sketches drawn by a painter, and thus to understand how the writing process itself develops.

In a letter the major aim of the writer is to communicate personal experiences to his or her addressee, so that preventing misunderstandings is essential, whereas in a poem like "Tintern Abbey" what matters is the verbal reconstruction of the experience triggered by the scene, the landscape itself being only part of the complete experience. The letters I have selected are all addressed to close friends and family of the letter-writers: Wordsworth's letters to his sister Dorothy from the Alps, and to his then friend Coleridge from Scotland; Shelley's letters to his friends Thomas Love Peacock and Elizabeth Hitchener from the Alps; and Keats's letters to his brother Tom and to his friend Reynolds from Scotland. Since these correspondents are closely related to the letter-writers, the distinction will be all the greater between these letters and poems meant for an anonymous audience, usually composed after time has elapsed and memory has reorganised the original experience.

d'œil", Emile Littré, Dictionnaire de la langue française), and thus the place where people live, or in other words their surroundings. In English, on the contrary, the first meaning of 'landscape' at once implies composition. See Oxford English Dictionary: "The word was introduced as a technical term of painters."

${ }^{2}$ Some of these letters actually turn into journal letters, with entries keeping track of each day, and a new form of relationship being established with the reader. This is especially true of Keats's letters to his brother while walking in Scotland, and of some of Byron's letters from the Alps to his half-sister Augusta. 
All these writers were nurtured on the theories of the sublime. They are familiar with the novels of Ann Radcliffe, some of which Coleridge reviewed favourably, stressing precisely her "powers of description". If we except Wordsworth, who spent his childhood in the Lake District, their preliminary contact with beautiful scenery was effected through works of literature, which shaped their first perceptions of the landscape. This cultural background proves to have a powerful influence on their letters; words related to the sublime are used almost mechanically by these poets, especially when they discover the Alps.

This influence is not perceptible in all the letters, however, and side by side with these essentially literary accounts, we discover other texts, pervaded by the emotional responses we have come to associate with romanticism. Thus, the letters also reveal a mode of writing landscape which throws light on later poetic compositions, and which confirms that far from being a brutal transformation, the move from picturesque vision to romantic Einfühlung was as erratic as some of the paths our travellers were taking.

Finally, because the code of letter-writing differs from that of poetry, if only because a good letter-writer should adapt to his correspondent instead of targeting an anonymous public, the poets put forward some aspects of their personality, through their reading/writing of landscape, that are absent from their poetry. In this respect, Keats deserves closer analysis, because he clearly stands apart from his contemporaries, mostly thanks to his humorous perceptions of landscape, which clearly mirror his bitter-sweet awareness of his own self in the world. Where the other poets see landscape either as essentially alien and awe-inspiring, or as a comforting motherly presence, Keats's introduction of humour indeed offers a more distanced view of the outside world, and of himself as a viewer.

\section{Sublime Clichés of Otherness}

\footnotetext{
3 Samuel Taylor Coleridge, Review of Ann Radcliffe, The Mysteries of Udolpho, The Critical Review, August, 1794, pp. 361-72. http://www.english.upenn.edu/ mgamer/Etexts/coleridge.reviews, accessed February $14^{\text {th }}, 2009$.
} 
All writers explicitly state that they have already read about the places they are about to admire. In 1816 Shelley and Byron even take a small tour in Switzerland with Rousseau's La Nouvelle Héloïse in hand because they want to confront the Swiss writer's words with the actual sights. They are enthusiastic, both about the quality of the text and about the beauty of the landscape:

This journey has been on every account delightful, but most especially, because then I first knew the divine beauty of Rousseau's imagination, as it exhibits itself in Julie [sic]. It is inconceivable what an enchantment the scene itself lends to those delineations, from which its own most touching charm arises. ("To Thomas Love Peacock," July $12^{\text {th }}, 1816$, The Letters of Percy Bysshe Shelley, I, 480)

Byron had also used the word "delineation" in his letter to John Cam Hobhouse, writing three weeks earlier: "Tomorrow we go to Meillerei - \& Clarens - \& Vevey - with Rousseau in hand - to see his scenery - according to his delineation in his Heloise [sic] now before me." (June $23^{\text {th }}, 1816$, Byron's Letters and Journals, V, 81). A few days later, writing to John Murray, he shares Shelley's reaction: "I have traversed all Rousseau's ground - with the Heloise [sic] before me $-\&$ am struck to a degree with the force \& accuracy of his descriptions $-\&$ the beauty of their reality:" (June $27^{\text {th }}, 1816$. Byron's Letters and Journals, V, 82). The verbal echoes prove that the two friends had been discussing the same book before looking at the scenery, and that before writing about the views, they had spent some time discussing Rousseau's description and confronting it with the reality, hence the repetition of the same words. In both letters Rousseau's text literally comes first, as the model against which the beauty of the actual scenery will be judged, thus proving that the art of description is considered to be superior to natural beauty. In fact, the landscape acts as a link between Rousseau and the British poets, confirming the affinity of their spirit. Byron's use of possessive forms ("his scenery", "Rousseau's ground" - italics mine) emphasizes how subordinated the landscape is to the writer's description of it. In every sense of the word, it is considered a view, a world-view even, hence the attention paid to the words used to describe it. 
However, when not spurred by such an experiment, Shelley uses vocabulary which calls to mind the tradition of the sublime, another world-view. Adjectives like "lofty", "elevated", "grand", or "awful" pepper his descriptions of the Alps, which are usually made of well-structured sentences which seem to refer to a painting more than to a natural setting. Here again, aesthetic tradition, as discovered through reading and through visual art, has shaped the writer's perception of the landscape. ${ }^{4}$

Similarly, when Wordsworth writes to his sister during his tour of France in September 1790, his letter hardly seems to come from the author of "Tintern Abbey", which was written only eight years later. Before describing the glaciers of the Alps, he warns Dorothy: "You have undoubtedly heard of these celebrated s[c]enes, but if you have not read of them any description which I have here room to give you must be altogether inadequate". ("To Dorothy Wordsworth", September $6^{\text {th }}, 1790$. The Letters of William and Dorothy Wordsworth, I, 33). This sentence again reveals the primacy of reading in his perception of new landscapes: before offering his own description of the Alps, he recalls the literary tradition to which his words belong. By alluding to other texts on landscape, he shows how textual any landscape is for him, and how coded any perception of it must be. In another letter, sent to Coleridge in December 1799, to which I will turn later, he even applies the word "introductory" to the banks of a river: "We were disappointed in the cascade though the introductory and accompanying banks were a noble mixture of grandeur and beauty" (December 24 ${ }^{\text {th }}, 1799$, The Letters of William and Dorothy Wordsworth, I, 278). The scenery is obviously a matter of words, and

\footnotetext{
${ }^{4}$ See for instance this letter sent to Thomas Love Peacock as he was walking in the Alps in 1816: "St-Gingoux is even more beautiful than Meillerie; the mountains are higher, and their loftiest points of elevation descend more abruptly to the lake. On high, the aerial summits still cherish great depths of snow in their ravines, and in the paths of their unseen torrents. One of the highest of these is called Roche de St. Julien, beneath whose pinnacles the forests become deeper and more extensive; the chestnut gives a peculiarity to the scene, which is most beautiful, and will make a picture in my memory, distinct from all other mountain scenes which I have ever before visited." (July $12^{\text {th }}, 1816$, Letters of Percy Bysshe Shelley, I, 484).
} 
these words fall into two categories, two genres: the sublime and the beautiful, as defined by eighteenth-century theories of landscape. ${ }^{5}$

After a few introductory remarks, he sums up his itinerary. It is worth quoting this rather long text in its entirety, as its very structure echoes the distinction between beautiful and sublime, presented almost pedagogically. Wordsworth starts with a comment on Lake Como:

It was with regret that we passed every turn of this charming path, where every new picture was purchased by the loss of another which we would never have been tired of gazing at. The shores of the lake consist of steeps covered with large sweeping woods of chestnut spotted with villages, some clinging from the summits of the advancing rocks, and others hiding themselves within their recesses. Nor was the surface of the lake less interesting than its shores; part of it glowing with the richest green and gold the reflexion of the illuminated woods and part shaded with a soft blue tint. The picture was still further diversified by the number of sails which stole lazily by us, as we paused in the woods above them. After all this we had the moon. It was impossible not to contrast that repose that complacency of Spirit, produced by these lovely scenes, with the sensations I had experienced two or three days before, in passing the Alps. At the lake of Como my mind ran thro a thousand dreams of happiness which might be enjoyed upon its banks, if heightened by conversation and the exercise of the social affections. Among the more awful scenes of the Alps, I had not a thought of man, or a single created being; my whole soul was turned to him who produced the terrible majesty before me." ("To Dorothy Wordsworth,' September 6" $6^{\text {th }} 1790$, The Letters of William and Dorothy Wordsworth, I, 33)

Wordsworth here contrasts the lake with the glaciers in a manner which evokes Radcliffe, who also made extensive use of these gendered overtones. The moon crowns the first vision of feminine beauty, which extols the softness of the lake. The Alps evoke divinity,

\footnotetext{
${ }^{5}$ At the beginning of the same letter, he writes: "My Spirits have been kept in a perpetual hurry of delight by the almost uninterrupted succession of sublime and beautiful objects which have passed before my eyes during the course of the last month." (The Letters of William and Dorothy Wordsworth, I, 32). Although "Spirits" does evoke his own response, he considers landscape to be sights "passing before his eyes," almost in cinematographic fashion. Like a more modern traveller, he tries to evoke postcards to share his experience with his sister.
} 
and there seems to be no doubt in Wordsworth's mind that the Creator is male. This description draws upon all the ingredients of the sublime and the beautiful, which have been summoned as a code for Dorothy to be able to imagine the scene. The view of the lake is clearly structured, starting from the shores before reaching the lake itself, and then the sails on the lake, with a definite movement from the general to the particular. The organising influence of the writer is made obvious by the syntax, but also by the time sequence, since Wordsworth does not respect chronology, and ends with the Alps so as to stress the contrast.

The poet returned to this journey in Book VI of The Prelude, which stresses the feelings of the speaker while discovering a landscape whose outline is, however, not clearly expressed in the poem. Letter and poem appear very different, the letter showing Wordsworth as an eighteenth-century man, where the poem, written fifteen years later, thrives on "emotion recollected in tranquillity," and thus signals a new form of expression, derived from a new manner of relating to nature:

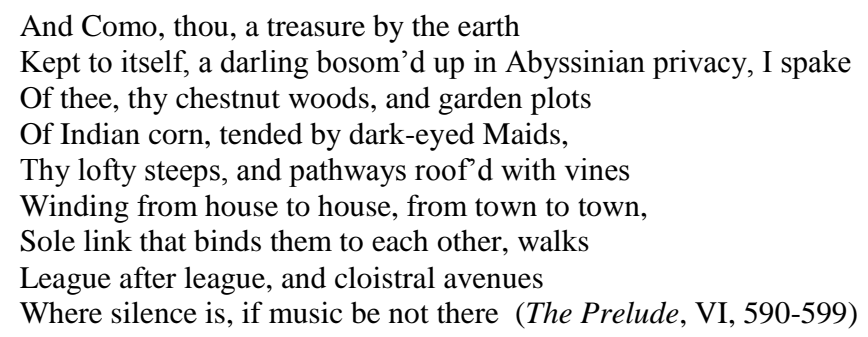

This passage already shows us two manners of writing landscape, and how in the second case the point is quite different from the first, although the gendered contrast between feminine lake and masculine mountain has been preserved. Very little remains from the impressions expressed in the original letter, which have been refashioned by memory and language into another vision altogether. The poem has obviously demanded more creative work, and the comparison between the two texts shows the difference between a mere account, already drawing from well-worn literary references, and a verbal creation, which depends upon its own effects and its own 
code, and attempts to conjure up a new vision, laden with associations, and not as close to the original experience.

Unlike his contemporaries, Keats rarely writes complex sentences; he favours coordination more than subordination and likes his prose to follow his trains of thought, even when they imply digressions or hesitations. He too makes use of the literary vocabulary of the sublime, although less often than his contemporaries: he is not as well-travelled and thus far more impressed with what he discovers; moreover his education was formally interrupted at the age of fourteen when he started his apprenticeship. The letters to which I refer were written during his walking tour of Scotland, begun in the Lake District where he was hoping to meet Wordsworth, a poet strongly associated with his native surroundings (here the French term 'paysage' pertains). Like his contemporaries, however, Keats has read Ann Radcliffe, but he acknowledges her influence with a touch of distance:

Buy a girdle - put a pebble in your Mouth - loosen your Braces - for I am going among Scenery whence I intend to tip you the Damosel Radcliffe - I'll cavern you, and grotto you, and waterfall you, and wood you, and water you, and immense-rock you, and tremendous sound you, and solitude you. ("To J. H. Reynolds," March $14^{\text {th }}, 1818$, The Letters of John Keats, I, 245)

When confronted with scenery, Keats often differs from his contemporaries, partly because he seems unable to take accepted literary descriptions seriously. He does, however, use words related to aesthetic theories of the landscape, and, when he travels across Scotland, his reference also comes from literature, predictably Burns, as in this letter written after reaching Ayr:

... then we set forward to Burnes's town Ayr - the Approach to it is extremely fine - quite outwent my expectations richly meadowed, wooded, heathed and rivuleted - with a grand Sea view terminated by the black Mountains of the isle of Annan. (...) The bonny Doon is the sweetest river I ever saw overhung with fine trees as far as we could see - we stood some time on the Brig across it, over which Tam o'shanter fled - we took a pinch of snuff on the key stone -" (To Tom Keats, July $13^{\text {th }}, 1818$, The Letters of John Keats, I, 331)

The rhythm of this sentence contrasts with the well-balanced periods of Wordsworth's letter to his sister; Keats is not composing a 
picture, he is inviting his brother to follow his footsteps mentally: his discovery of the landscape is related chronologically, and the way he himself stood over the bridge matters as much as the river. Thus, Keats as a letter-writer proves more respectful of the requirements of the genre than Wordsworth ${ }^{6}$, or perhaps less influenced by literary conventions. $^{7}$

Nevertheless, this excerpt also shows that even Keats's perceptions of Scotland have been influenced by his readings. In all the letters I have been referring to, the landscape is being read as if it were a poem, for the aesthetic emotion it triggers in the viewer, and with great attention paid to codes. Indeed, these poets tend to use the word "scenery", which originally referred to the stage. The stress is on distance, which enables the viewer to see clearly, and which is expressed by language and the way it is structured. What the epistolary form here reveals is how each writer's personality leads him to choose a different code, to read the landscape in his own idiosyncratic way. In this respect, education and culture obviously play an essential part, since they inform the writers' very perception of the landscape.

However, when writing to their friends and family about their experiences, these poets simultaneously try to recapture feelings. Keats has a revealing metaphor for this process in a letter to Reynolds, which is not without evoking "emotion recollected in tranquillity": "I endeavour'd to drink in the Prospect, so that I might spin it out to you as the silkworm makes silk from Mulbery leaves" (July $13^{\text {th }}, 1818$, The Letters of John Keats, I, 323). Because they are eager to convey their own response to the sights, the poets then choose words which are not as dependent on conventions. Their letters start to focus on the beholder more than on the thing of beauty, with each writer putting forward his own world-view. The landscape is no longer considered a beautiful yet distant object to be admired, but more as a part of the human range of experience; this in turn entails some stylistic changes,

\footnotetext{
${ }^{6}$ However, this should not surprise us, from the poet who claimed to be a "chameleon poet", with no personal identity, and opposed himself to Wordsworth's "egotistical sublime".

${ }^{7}$ See Marjorie Levinson, Keats's Life of Allegory, for a thorough discussion of Keats' education, and its shortcomings.
} 
and we now meet the language usually associated with the romantic experience of nature.

\section{Within the Womb of Mother Nature?}

One can recognize Byron's sense of humour when, in a journal letter to his half-sister Augusta, he personifies a mountain in the following terms: "Arrived at a lake in the very nipple of the bosom of the Mountain" (September 19 $9^{\text {th }}$ 1816, Byron's Letters and Journals, $\mathrm{V}, 98$ ). This metaphor is more revealing of Byron's character than of the actual landscape, and one could not imagine it in one of Radcliffe's novels, if only because she usually perceives mountains as male. This gradual feminization of the landscape can be traced through all the letters I have read, and will predominate in English Romantic poetry.

Wordsworth's tone also changes when, during his tour of Scotland with his sister, he writes to Coleridge about his feelings before a waterfall. He no longer resorts to the clichés of a tourist after visiting a famous scene; he is now analysing his feelings as a poet and wondering about expression:

I cannot express to you the enchanted effect produced by this Arabian scene of colour as the wind blew aside the great waterfall behind which we stood and hid and revealed each of these faery cataracts in irregular succession or displayed them with various gradations of distinctness, as the intervening spray was thickened or dispersed. In the luxury of our imaginations we could not help feeding on the pleasure which in the heat of a July noon this cavern would spread through a frame exquisitely sensible.That huge rock of ivy on the right! the bank winding round on the left with all the living foliage, and the breeze stealing up the valley and bedewing the cavern with the faintest imaginable spray. (December $27^{\text {th }}, 1799$, The Letters of William and Dorothy Wordsworth I, 280)

Of course, time has passed, and he is writing to his friend, a poet he respects, more equal to him than his young sister. In the meantime, he has probably discussed his perceptions of nature with Coleridge, he has written some of his now famous poems, and the letter reflects this evolution, as well as the change due to the addressee. Here we discover the words of a creator analysing his 
response to beauty and already wondering about the best manner of transmuting his feeling into words, whereas in the Alps, he was just borrowing the easiest formulae to convey his experience. Very few of his letters attain this degree of enthusiasm, or express such an open acknowledgement of pleasure. The main difference between this description and the one he sent Dorothy is the physical presence of the spectators. They are standing in the middle of the landscape instead of watching it from a distance; this physical closeness is conveyed by a tone which appears far more subjective and emotional than the description of Como and the Alps, either in prose or poetry. Although Wordsworth's way of personifying the landscape may be more refined than Byron's, his description also transforms parts of the landscape such as the bank, the foliage, and the breeze into animated elements. Thus, the line between the viewer and the outside world, which was made more perceptible by the vocabulary of the sublime and the shaping influence of syntax, is here blurred. What prevails is a feeling of harmony between man and nature, with a distinct focus on the viewer's feelings, which matter more than the object he is watching, and thus pervade the description, mainly through personification devices. Wordsworth's sentences have changed: they even include a nominal clause at the end, quite unlike the well-structured periods quoted earlier.

In a letter to his friend Elizabeth Hitchener, Shelley goes further; he is writing from Wales: "We are now embosomed in the solitude of mountains woods \& rivers, silent, solitary, and old, far from any town, 6 miles from Rhayader which is nearest" (April $16^{\text {th }}$, 1812, The Letters of Percy Bysshe Shelley, I, 283). All the adjectives can apply either to the human "we" or to the natural elements. Shelley's letter also illustrates how the landscape is being deconstructed into ingredients, elements which can eventually turn into symbols, like the West Wind, or the Skylark, or the Cuckoo if we think of Wordsworth, or even Keats's Nightingale. Here again, the organisation of the words through syntax, with the adjectives being postponed in an appositive device, blurs the frontier between viewer and landscape. No exact scene could be visualised from this description, which chooses to focus on other senses than sight.

When Keats starts composing his great odes, his letters, which have always shown his love of words and language, fully act as a 
creative workshop, in which we find echoes of the poems he is working on. The most interesting case is the letter written to Reynolds after he composed his ode "To Autumn" in September 1819:

How beautiful the season is now - How fine the air. A temperate sharpness about it. Really, without joking, chaste weather Dian skies - I never lik'd stubble fields so much as now - Aye better than the chilly green of the spring. Somehow a stubble plain looks warm - in the same way that some pictures look warm - this struck me so much in my sunday's walk that I composed upon it. I hope you are better employed than in gaping after weather." (September 21th, 1819, The Letters of John Keats, II 166)

Not only is the landscape personified once again, and even deified by Keats, it is enlarged to include the season. As the last sentence shows, Keats has indeed been watching the weather, just as he was watching the mountains of Scotland the year before. However, instead of concentrating on describing the season in precise words, he tries to sketch a wider vision, and by using metaphors and synaesthesia, he reverts to the poetic mood in which he composed "To Autumn". What is considered landscape has changed as much as the perception of it. Like the other poets, Keats is here describing a universe in which the line between animate and inanimate is blurred, in which what we see is only part of what we feel, and in which the scenery, which has become feminine, acts as a form of inspired setting. ${ }^{8}$

In this manner, the representation of landscape evolves in these letters, which also allows us to understand how one of the key poetic figures representing nature in the Romantic Age becomes the bower. This is especially clear with Keats, of course, but we can also think of Coleridge's conversation poems, or even, again, of "Tintern Abbey". Instead of letting the eye perceive the elements of a landscape, which is organised spatially, the poem will foreground sensations such as

\footnotetext{
${ }^{8}$ Towards the end of his tour of Scotland, Keats was showing more interest in the people he met than in the mountains and waterfalls. His Scottish experience can be seen in the opening of Hyperion, although his debt to the Scottish landscape had then been transmuted into a poetic element, used for the overall effect of the poem, and had ceased to be a thing to look at for its own beauty. This recalls Wordsworth using his visit to Como as a pretext to analyse the growth of his poet's mind.
} 
smell, sound and touch, because nature is to be felt even more than seen. What the poem will try to render is the effect of one element of nature on the speaker, because of the harmony established between the two. Sublime landscapes are gradually becoming too lofty, and a more feminine presence of nature is evoked, one which, incidentally, can be mastered more easily by the male poet's consciousness.

In the letters written by these poets, we witness the process through which past heritage is being transmuted into a new form of creation: because the essential aim of a letter is to communicate a message to an addressee, these poets try to share their experiences when travelling and quite naturally tend to use their literary (even more than pictorial) knowledge. However, as we have seen, we can also trace the birth of a new conception of nature, in which the distant landscape is gradually becoming closer, and thus humanized. The epistolary genre makes it possible for complementary - sometimes contradictory! - visions to co-exist; letter-writers adapt to their addressees, and young Wordsworth writing to his sister does not focus on the same elements as Wordsworth the poet writing to his fellowpoet Coleridge. I started by mentioning the common cultural background: this changes with the letter-writer, and also with the addressee. Thus, Keats does not share his contemporaries' views, mostly because unlike them, he never went to college: besides, he keeps his satire of Radcliffe for his poet-friend Reynolds, and tries to be more down-to-earth for his brother.

Composing poetry entails significant differences: instead of a known addressee, a poet tries to touch an anonymous audience. The point will no longer be to testify to what has been discovered, and landscape becomes used as part of a larger design, the setting of Hyperion in Keats's case, or the object which will cristallize remembrance in "Tintern Abbey".

Indeed, Keats's specificity lies in his being able to use humour in his descriptions of the landscapes. He thus proves his ability to establish some distance; he can look at the scenery while being aware of the literary tradition that has provided words to describe it, and while making fun of this tradition, and of his following the tradition, at the same time. This sense of humour is almost entirely absent from his poetic writings, and this new distance perhaps owes a little to his 
being part of the second generation of Romantics, able to look back on what his elders have created.

\section{Keats's Humorous Distance from the Landscape}

As we have seen, as a letter-writer Keats never lets his correspondents forget his presence, either as a walking watcher, whose moving eye has filtered the scene, or as a writer who is intent on sharing his experience. Where his contemporaries concentrate on the views they have admired, he rarely resists including some remarks about the state of his feet, or the food he has eaten - or not, as the case may be.

This intrusion of body language into the middle of sublime sights characterises his letters from Scotland, and very often creates comic effects, as when he sums up the beginning of the walking tour for his friend Reynolds:

I'll not run over the Ground we have passed, that would be merely as bad as telling a dream - unless perhaps I do it in the manner of the Laputan printing press - that is I put down Mountains, Rivers Lakes, dells, glens, Rocks, and Clouds, With beautiful enchanting, gothic picturesque fine, delightful, enchancting, Grand, sublime - a few Blisters \&c - and now you have our journey thus far: (July $11^{\text {th }}$, 1818, The Letters of John Keats, I, 322)

Once again literary influences are conspicuous, but what is more characteristic of Keats is his introduction of the blisters almost next to the adjective "sublime", and set apart by dashes. The enumeration of elements from nature, with hackneyed adjectives to qualify them, transforms the beauties of Scotland into a mere list of ingredients, almost a checklist, in which the same qualifier is repeated, as if to stress the poverty of language, whereas the blisters clearly stand out. Like Shelley, Keats deconstructs the landscape into parts, but because of the weight created by the enumeration and of the intrusion of physical pain, the letter shows how relative beauty actually is. Thus his aching body is more highlighted than his emotion on beholding natural beauty. As the beginning of the excerpt makes it clear, this letter was written after he had already travelled a few days, 
during which he had written to his brother Tom almost every day, which accounts for the fact that this is a summary of what he has already written.

However, this should not prevent us from noting the difference between such a way of writing the landscape and the texts we have been reading so far. By using humour, Keats is keeping emotion at bay, and by introducing suffering, especially as minor and yet potentially annoying as a blister, he also diverts the reader's attention from the landscape to himself, not as the perfect picturesque or sublime traveller, lost in awe in front of the landscape, but as a mundane, pedestrian traveller, who retains enough sense to feel the discomfort.

His epistolary parody of Radcliffe had already revealed his awareness of the potentially ridiculous descriptions sublime sights might lead to. By reminding the reader of his body, instead of focussing on his soul, he goes one step further and stresses the fact that experiencing the landscape is not only harmonious communion. In this letter to Reynolds, he thus distances himself both from Radcliffe and from Wordsworth, the great romantic walker, the man he had tried to visit on his way to Scotland, and who had disappointed him by canvassing for Lowther. ${ }^{9}$ Humour enables him to look at his own disappointment with some distance.

That is why, although he enjoyed his walking tour of Scotland, and learned much from his experiences there, when he concludes the tour, compelled to sail back to London because of a persistent sore throat, he returns to humour to describe both his movements and the sights, thus proving again his awareness of having behaved after a fashion, and of the potential ridicule of the whole enterprise:

I must leave joking \& seriously aver, that I have been werry romantic indeed, among these Mountains \& Lakes. I have got wet through day after day, eaten oat cake, $\&$ drank whiskey, walked up to my knees in Bog, got a sore throat, gone to see Icolmkill \& Staffa, met with wholesome food, just here \& there as it happened; went up Ben Nevis, \& N. B. came down again; Sometimes when I am rather tired, I lean rather languishingly on a Rock, \& long for some famous Beauty to get down from her Palfrey in passing; approach me with - her

\footnotetext{
${ }^{9}$ See Coote 1995: 162-163.
} 
saddle bags - \& give me - a dozen or two capital roast beef sandwiches - When I come into a large town, you know there is no putting ones Knapsack into ones fob; so the people stare - We have been taken for Spectacle venders, Razor sellers, Jewellers, travelling linnen drapers, Spies Excisemen, \& many things else, I have no idea of - ("To Mrs Wylie," August $6^{\text {th }}, 1818$, The Letters of John Keats, I, 359-60)

Here again enumeration is used to place the landscape among a list of other experiences, in other words to make it relative. Keats's aim in going to Scotland was to see natural beauty, which as a Londoner, he was not familiar with. He hoped the walking tour would inspire him as a poet, and this indeed happened. He also hoped the tour would enable him to build his own sense of identity, and the end of this excerpt shows that doubt still prevailed in that respect, although humour is there to make it tolerable for the writer. Humour is first used as a general device, which characterises a certain mode of travelling to see the sights, but it then revolves onto the writer himself, at the end of the text.

Like the letter to Reynolds, this text is a summary, which is based on distance, on reorganising experience after time has elapsed. However, Keats also writes humorous accounts in a more immediate context. After climbing Ben Nevis, he sits down to write a long letter to his brother Tom. The first part of the letter focuses on his experience, and as usual in his letters, the account is chronological, so as to enable Tom to retrace his brother's footsteps. Once he has reached the top, the letter-writer tries to convey his perceptions as he was discovering the view, partly hidden in the mist:

I do not know whether I can give you an Idea of the prospect from a large Mountain top - You are on a stony plain which of course makes you forget you are on any but low ground - the horizon or rather edges of this plain being above 4000 feet above the Sea hide all the Country immediately beneath you, so that the next objects you see all round next to the edges of the flat top are the Summits of Mountains of some distance off - as you move about on all side[s] you see more or less of the near neighbour country according as the Mountain you stand upon is in different parts steep or rounded - but the most new thing of all is the sudden leap of the eye from the extremity of what appears a plain into so vast a distance On <those> one part of the top there is a handsome pile of stones done pointedly by some soldiers of artillery, I climbed onto them and so got a little 


\begin{abstract}
higher than old Ben himself. I was not so <clo> cold as I expected yet cold enough for a glass of Wiskey [sic] now and then - There is not a more fickle thing than the top of a Mountain - what would a Lady give to change her head-dress as often and with as little trouble! (...) I have said nothing yet of our getting on among the loose stones large and small sometimes on<e> two sometimes on three and stick, then four again, then two $\{$,$\} then a jump, so that we kept on ringing$ changes on foot, hand, Stick, jump boggl $\{e$,$\} s[t]umble, foot, hand,$ foot, (very gingerly) stick again, and then again a game at all fours. (August $3^{\text {rd }}, 1818$, The Letters of John Keats, I, 354)
\end{abstract}

The movement of Keats's account is here obvious: this is only part of the letter, but it does show that he first attempts to describe the scenery, the view from the top, and feels unequal to the task. Thus he first uses humour to personify the mountain, by comparing it to a fickle lady, before turning on himself as a poor climber. The landscape is here perceived in the way it interacts with the viewer, both through the personification of Ben Nevis and through the very concrete description of the walker's progress up the mountain. Once again, Keats introduces a bodily awareness of the viewer as more than a detached presence, looking at the view. In this respect, the phrase "leap of the eye" contributes to the overall movement: even watching is active in this account. By focussing on movement, Keats also supersedes emotion. He pushes the game a little further in the same letter by referring to a very fat lady who climbed the mountain, and imagining a scene from a play, in which the lady is made to address Ben Nevis.

With these humorous letters, we can discover a new manner of writing landscape, grounded on interaction between the viewer and the world. This introduction of movement characterises Keats's visions of Scotland. His amused awareness of himself as traveller, and as writer having read about landscapes before thus provides a double-edged comment on his contemporaries. He too is following the fashion of the day, he too is enjoying the sights, but he is trying to remain aware of the part played by convention in his enterprise.

This overview of romantic letters has shown how literary any vision of landscape is. This is perhaps one of the reasons why tourists 
use guide books, a genre, which, incidentally, started to flourish at the time of romanticism. Guide books exist to help their readers anticipate foreign landscapes; therefore any discovery of landscape has often first been fashioned by words, which act as a way of taming alien surroundings by referring to them in familiar terms, thus making them more acceptable. For learned travellers, literary texts or poems play the same part, and some of us visit some places as Byron and Shelley did, so as to discover scenery we have read about in literature. As a scholar in romanticism, I made a point of looking at the ruins of Tintern Abbey as I was travelling in Wales, and like many others before - and after! - me, I also followed Keats's footsteps in Scotland, comparing my impressions with his epistolary accounts, with a sense of anticipation. Had I decided to write an account of my journey, Keats's words would have been present in my mind, both as a familiar reference and as a form of constraint, channelling my impressions. Landscape is not merely nature, it is a human construction and organisation of space, and that is why verbal constructions which depict it tend to structure our perceptions.

Moreover, landscape may change according to point of view, depending on whether it is being seen from a distance or close up, and the text that describes this vision will also change. In some cases, the sense of sight will predominate, and what the reader is given is an image, whereas when the viewer stands in the middle of landscape, other senses come into play, thus greatly changing both perception and description. In other words, landscape is not always depicted as static, and a traveller will also have to include movement when describing landscape. In Keats's case, this takes on a humorous, physical dimension. Because nature played such a significant part in their experience, and because they were writing after the fashion of the picturesque and the sublime, which had transformed nature into potential works of art, the Romantics helped redefine our awareness of landscape, and consequently our writing of it.

Finally, I would like to change continents, and quote words written by the American explorer Meriwether Lewis, during what became known as the Lewis and Clark expedition. In 1805, as they were reaching the Missouri falls, Lewis attempts to describe the landscape in his journal: after a few lines in which intensifiers and superlatives abound, showing his emotion and his difficulty in 
rendering what he has seen, he gives up and laments the fact that he cannot draw the landscape. The words he uses are significant, mostly because of the way in which he spells the verb "to write": "after wrighting this imperfect discription [sic] I again viewed the falls and was so much disgusted with the imperfect idea it conveyed of the scene that I determined to draw my pen across it and begin agin [ sic]..." 10

This original spelling says it all: writing landscape is also a way for poets to make the landscape right, to erase all the chaotic disorder of nature thanks to well-organised words. This is why Keats's humour is more subversive than it might appear: by perverting the established code and by showing his awareness of the artificial nature of language, he also stresses that landscape has to be considered as an artefact.

Université de Bourgogne

Bibliography

Primary References

Jones, Frederick, (ed). 1964. The Letters of Percy Bysshe Shelley. London: Oxford at the Clarendon Press. 2 vols.

Marchand, Leslie, (ed). 1973. Byron's Letters and Journals. London: John Murray. 12 vols.

Rollins, Hyder Edward, (ed). 1976 [1958]. The Letters of John Keats. 1814 - 1821. Harvard, Mass.: Harvard University Press. 2 vols.

Shaver, Chester L. (ed). 1967. The Letters of William and Dorothy Wordsworth. London: Oxford University Press. 3 vols.

Thwaites, Gold (ed). 1904. Original Journals of the Lewis and Clark Expedition, 1804 - 1806. New York: Dodd, Mead. 8 vols.

${ }^{10}$ Original Journals of the Lewis and Clark Expedition, 1804-1806, 2: 15356. 


\section{Secondary References}

Baridon, Michel. 2006. Naissance et renaissance du paysage. Arles : Actes Sud.

Coote, Stephen. John Keats. A Life. 1995. London: Hodder and Stoughton.

Hussey, Christopher. 1983. The Picturesque. Studies in a Point of View, London: Frank Cass \& Co.

Levinson, Marjorie. 1988. Keats's Life of Allegory: the Origins of a Style. Oxford: Blackwell.

Index

Addressee, 2, 3, 10, 13, 14

Aesthetics, 4, 5, 8, 9

Alps, 2, 3, 5, 6, 7, 11

Burns, Robert, 8

Coleridge, Samuel Taylor, 2, 3, 5, 10, 12,13

Description, 3, 4, 5, 7, 8, 11, 15, 17 , 18

Emotion, 2 , 7, 9, 10, 11, 14, 15, 17, 18

Experience, 2, 8, 9, 10, 11, 13, 14, 15, 16,18

Gender, 6, 7, 10, 12, 13

Gordon, Lord Byron, 4, 10, 11, 18

Hitchener, Elizabeth, 2, 11

Humour, 3, 13, 14, 15, 16, 17

Hussey, Christopher, 1

Keats, John, 2, 3, 8, 9, 11, 12, 13, 14, $16,17,18,19$

Keats, Thomas, 2, 15, 16

Lake Como, 6, 7

Lewis, Meriwether, 18

Memory, 2, 7
Peacock, Thomas Love, 2

Perception, 1, 3, 5, 9, 10, 12, 16, 18

Picturesque, 1, 3, 15

Radcliffe, Ann, 3, 6, 8, 10, 13, 15

Reading, 4, 5, 9

Representation, 2, 12

Response, 1, 3, 11

Reynolds, John Hamilton, 2, 9, 12, $14,15,16$

Rousseau, Jean-Jacques, 4

Scotland, 2, 8, 9, 10, 12, 14, 15, 16, 17, 18

Shelley, Percy Bysshe, 2, 4, 5, 11, 14, 18

Sublime, 3, 5, 6, 7, 8, 11, 13, 14, 15, 18

Switzerland, 4

Wales, 11,18

Wordsworth, Dorothy, 2, 5, 7, 11

Wordsworth, William, 1, 3, 5, 6, 7, 8, $9,10,11,13,15$

World-view, 4, 9 